\title{
Introductory address for the American Pediatric Society's 2015 John Howland Award Recipient, Catherine D. DeAngelis
}

\author{
Modena E. Wilson ${ }^{1}$
}

Presented by Julia A. McMillan, MD, Professor of Pediatrics, Executive Vice Chair, Department of Pediatrics, and Associate Dean for Graduate Medical Education, Johns Hopkins University School of Medicine, at the 2015 Annual Meeting of the Pediatric Academic Societies, San Diego, CA.

$\mathrm{s}$ there a pediatrician whose professional life has not been influenced by the 2015 John Howland Award winnerDr Catherine D. DeAngelis? I doubt it. Dr DeAngelis's contributions are deeply rooted in our profession. Her work, which has both enriched and transcended pediatrics, is encapsulated by a subtitle-Leadership for All Ages.

It is a privilege to introduce Cathy as the winner of the 2015 John Howland Award. I have had the benefit of working alongside Cathy for large stretches of my professional career. She has been my teacher, my mentor, my boss, my colleague, my children's pediatrician, and my friend. The occasion of this award, however, requires a more objective perspective on what she has achieved. Whether viewed from close-up or from afar, Dr DeAngelis is an extraordinarily gifted leader. She has used her talents, positions, and passions for the betterment of patients, the public, and our profession. Her leadership is best demonstrated, I believe, by a review of the ever-widening stages in and on which her career has played out (Table 1).

\section{STAGE 0: PREPARATION}

Cathy grew up near Scranton, Pennsylvania, in a warm and supportive family but in a time and circumstance that did not foreshadow a career in medicine, let alone a powerful one. She earned her RN credential and practiced as a nurse, but her aptitude for medicine was quickly recognized, and she was encouraged to go to medical school. She received a BA from Wilkes College and her MD degree from the University of Pittsburgh. After internship in pediatrics at the Children's Hospital there, she completed pediatric residency at the Johns Hopkins Hospital in Baltimore. It was there that she met Dr James Harris, now a distinguished academic physician in his own right, whom she would marry in 1979. Following residency, Cathy served as a pediatrician at Roxbury Comprehensive Health Clinic in Boston while she studied public health at Harvard.

\section{STAGE 1: GETTING STARTED}

Dr DeAngelis then joined the College of Physicians and Surgeons and the School of Public Health at Columbia University as an Assistant Professor establishing what would be a multiyear commitment to academic medicine.

She moved from Columbia to the University of Wisconsin where she directed ambulatory pediatric services and was promoted to Associate Professor.

\section{STAGE 2: JOHNS HOPKINS DEPARTMENT OF PEDIATRICS}

In 1978, Cathy returned to Johns Hopkins as an Associate Professor to establish an academic generalist presence there as Director of Pediatric Primary Care and Adolescent Medicine. She established a fellowship program and clinical programs, including a continuity clinic for Harriet Lane pediatric residents, and in 1984, she became the founding director of a formal Division of General Pediatrics and Adolescent Medicine. The programs she initiated still thrive as do their rich connections with the Bloomberg School of Public Health where Cathy held a joint appointment.

In 1986, Cathy was promoted to Professor, becoming only the 12th woman to achieve that rank in the School of Medicine. That she did so as a generalist was perhaps even more unusual.

\section{STAGE 3: NATIONAL LEADERSHIP IN PEDIATRICS}

All through stages 2 and 3, Cathy was contributing to pediatrics at the national level, actively engaged at one time or another in the full array of organizations that determine how pediatrics is taught and practiced, rising in each to an apex leadership position. When at the leadership level, Cathy was never there merely to conserve. She used the leverage those positions offered to advance the field.

\section{STAGE 4: JOHNS HOPKINS SCHOOL OF MEDICINE}

In the last decade of last century, Cathy's work at Johns Hopkins moved fully to the School of Medicine level with responsibility for Academic Affairs and Faculty. Never one to avoid challenges, once there, she continued to drive change.

During that period, she became Editor-in-Chief of Archives of Pediatrics and Adolescent Medicine, now JAMA-Pediatrics. That editorship can now be recognized as a harbinger of the 


\section{Introduction to 2015 Howland Award recipient $\quad$ Special Article}

Table 1. Catherine D. DeAngelis career stages

\begin{tabular}{|c|c|}
\hline \multirow[t]{2}{*}{ Stage 0} & Preparation, education, and training \\
\hline & RN, BA, MD, Pediatric Residency, MPH \\
\hline \multirow[t]{3}{*}{ Stage 1} & Getting started-Assistant Professor to Associate \\
\hline & Columbia University (1973-1975) \\
\hline & University of Wisconsin (1975-1978) \\
\hline \multirow[t]{2}{*}{ Stage 2} & $\begin{array}{l}\text { Johns Hopkins University_Associate Professor } \\
\text { to Professor }\end{array}$ \\
\hline & Department of Pediatrics Focus (1978-1990) \\
\hline Stage 3 & National Leadership in Pediatrics (1985-2000) \\
\hline \multirow[t]{2}{*}{ Stage 4} & Johns Hopkins University \\
\hline & School of Medicine Focus (1990-2000) \\
\hline \multirow[t]{4}{*}{ Stage 5} & The Nation and the World (2000-2011) \\
\hline & Editor-in-Chief, JAMA \\
\hline & $\begin{array}{l}\text { Editor-in-Chief, Scientific Publication and } \\
\text { Multimedia Applications }\end{array}$ \\
\hline & American Medical Association \\
\hline Stage 6 & Leader for all ages \\
\hline
\end{tabular}

next stage in her career at the full national and international level, in keeping with influence that had already become both deep and broad. I would note in particular for a pediatric audience, that Cathy received the George Armstrong Award in 1990, the Joseph W St Geme Jr Leadership Award in 1998, and the Abraham Jacobi Award in 2000.

\section{STAGE 5: THE NATION AND THE WORLD}

Cathy took a leave of absence from Hopkins in 2000 to assume the role for which those outside of pediatrics have come to know her best-Editor-in-Chief of JAMA, a journal she took to a whole new level, serving until 2011 at JAMA and as Editor-in-Chief of Scientific Publications and Multimedia Applications at the American Medical Association.

\section{LEADERSHIP ACHIEVEMENTS}

It is not the numerical weight but the quality and breadth of Dr DeAngelis's contributions not only to pediatrics but to the art and science of medicine in general which make her deserving of the Howland Award. Of her many areas of achievement, highlights are the following (Table 2):

Team-based care: Cathy recognized early the potential of advanced practice nursing in pediatrics. She helped develop training for pediatric nurse practitioners, and she incorporated nurse practitioners into clinical services in a way that taught by example a generation of residents and fellows the value of collaborative care models.

School-based health care: As the Director of the Robert Wood Johnson Foundation National School Health Program, Cathy demonstrated in the early 1980s the potential of schoolbased clinical care.

General academic pediatrics: Aided by General Pediatric Academic Development Fellowship Program grants from the Robert Wood Johnson Foundation, Cathy, along with a handful of other giants in general pediatrics, was key to the
Table 2. Leadership achievements of Catherine D. DeAngelis

Team-based care

School-based healthcare

General academic pediatrics

Adolescent medicine

Medical education across the continuum

Women in medicine

Integrity in medical journalism

Medicine as a profession/professionalism

establishment of the field of general academic pediatrics which has now been institutionalized in pediatric departments around the nation.

Adolescent medicine: Cathy's attention to the medical and psychosocial needs of adolescents raised awareness of the important developmental and medical issues they confront and was influential in the efforts that led to subspecialty certification for adolescent medicine as a discipline of pediatrics.

Medical education across the continuum: Cathy has been an innovator in medical education. She has not only worked to develop models that ensure the highest quality medical education and training, she has turned her attention to helping physicians develop the knowledge and skills to lead the healthcare system. A tangible example is the certificate program in the business of medicine she conceived and implemented at Johns Hopkins.

Women in medicine: Cathy has been a champion for women in medicine at the local level and beyond. It is fitting that an endowed Catherine DeAngelis Visiting Lectureship for Women in Medicine was established at Johns Hopkins in 2000, and in June 2013, she was presented with the Lifetime Achievement Award for the Advancement of Women by the Johns Hopkins Office of Women in Science and Medicine.

Integrity in medical journalism: Cathy is now best known for editing JAMA and for all she accomplished in that role. And it is a particular focus of that editorship that may prove to be her most long-lasting and powerful legacy, that is, the clarity with which she advocated for, and the processes she created to support, transparency around conflicts of interest that can distort medical research and reporting of results.

Medicine as a profession/professionalism: Cathy now devotes her time even more explicitly to thinking and writing about professionalism (1) - and one can see how each of the prior leadership areas contributes to a holistic expression of what it means to be a member of the healing profession. It is a profession of which Dr Catherine D. DeAngelis is a star example.

\section{STAGE 6: LEADER FOR ALL AGES}

Cathy is never more at home that when she is at Hopkins where she returned in 2012. The dome is her touchstone. I met Cathy in the bustling concourse of Hopkins's shiny new hospital early this year. 


\section{Special Article | wison}

The next half hour gave me new inspiration for introducing her as the 2015 Howland Awardee. I realized I had been thinking of Cathy's leadership spelled with a capital "L"-that is, as it operated and influenced at the organizational, institutional, national, and international levels. During the next few minutes of a single morning, I was reminded in real time that she also is a magnetic leader at the lower case "l" level-inspiring, advising, and assisting one person at a time.

In the coffee line, a resident in scrubs and white coat, stethoscope in pocket, held up the line to introduce himself to Cathy and say how much he had appreciated a Grand Rounds presentation she had given on professionalism in his department. Next, an Associate Professor joined us at the table to ask Cathy for advice about which international medical aid group to support. An accomplished health services researcher from the Bloomberg School of Public Health whom Cathy had mentored sat down to touch base. Finally, a professor of surgery on patient rounds happened by, stopping when he saw Cathy to share with her his concern about the slow pace of the research trajectory of a junior faculty member.

"Send her to me," Cathy said.

Many of us have had the good fortune of being "sent to" Cathy literally or figuratively during the more than $50 \mathrm{y}$ of her career. In conferring the 2015 John Howland Award, we celebrate her with affection, her achievements with admiration, and her career with more than a touch of awe as we add to her many honors this one which she may value above all others.

\section{ACKNOWLEDGMENT}

The author wishes to thank Julia McMillan for her helpful comments and for presenting the introduction during the award ceremony.

\section{REFERENCE}

1. DeAngelis CD, ed. Patient Care and Professionalism. New York: Oxford University Press, 2014. 